\title{
The Growth of Urban Slums and Conflicts in Nigeria: A Case Study of Jos and Environs 1980-2010
}

\author{
Ajiji David Nyam and Larab Tangshak Ayuba
}

\begin{abstract}
The study attempts an explanation between the growth of urban slums and conflicts in Jos and also the period of upheavals in the North from 1980-2010.The study in historical perspective takes from the late 1960s tracing the waves of migration into the area as a safe haven. The authors' arguments are to the fact that the growth of urban slums supported the circle of violence and prolonged its spiralling and recurrence over a decade. The work in its source adopts oral interviews and archival sources as primary in ascertaining the dynamics, patterns of change, wave of movements and reasons for the escalation of conflicts and effects. The work takes to content analysis of secondary source literatures in defining the narratives that gives the paper its value. The method of interpretation is analytical, descriptive and narrative in its explanation highlighting the correlates of the issues under review. The paper submits by way of conclusion suggestions and strategies to forestall future escalation of conflicts in cosmopolitan settings.
\end{abstract}

Index Terms - Growth, urban slums, rise of conflicts and cosmopolitan cities.

\section{INTRODUCTION}

One of the endemic problems facing Nigeria today is inter-ethnic conflicts. Although this phenomenon manifests itself across the whole country, it is more pronounced in some parts than in others. The lower part of the North, generally known as the Middle Belt, suffers from it more than the upper part, also variously known as the 'Muslim North', the 'far North' and the 'Emirate North'. Moreover, the crisis became particularly acute in the last two decades of the $20^{\text {th }}$ Century and the momentum seems to be sustained ever since.

The degree of violence to both life and property that accompanies these conflicts raises fundamental questions about their causes and possible solutions. Various factors have been advanced to explain the upheavals. They range from the conventional arguments like attempts by some religious or ethnic groups to change what they perceive as unfavorable configuration of economic and political power in particular religious or geo-political entities in the country. This paper examines the growth of urban slums and conflicts in Nigeria with special emphasis on Jos Plateau and environs from 1980-2010 and the impact they have had on the development of inter-ethnic and religious conflicts in Nigeria.

Jos town is the capital of Plateau State, Nigeria and of Jos

Manuscript received October 3, 2014; revised January 20, 2015.

Ajiji David Nyam is with the Federal University Lafia, P.M.B 146, Lafia, Nasarawa State, Nigeria (e-mail:davidnyamajiji@yahoo.com).

LarabTangshakAyuba is with the University of Jos, P.M.B 2084, Jos, Plateau State, Nigeria (e-mail:larabtang@gmail.com).
North Local Government of Plateau State. It is located at the Northern part of Plateau which bears its name at an elevation of about $1,200 \mathrm{~m}$ above sea level. As a town, it is the mostasymmetrically placed state capital in the whole of Nigeria, located at the extreme northern end of the state [1].

Except on its northern part, the town is almost surrounded by hills. To the east are the Dogon Dutse and Shere Hills which rise to over $1,300 \mathrm{~m}$ and $1,400 \mathrm{~m}$ respectively. On the western side are the Jentar Hills which also rise to over $1,280 \mathrm{~m}$ above sea level. To the south are many small inselbergs and rocky out crops. In the north the topography is worsened by many unclaimed old mining paddocks although a few of these have been reclaimed. On account of its altitude, Jos town experiences cooler temperature and in some cases higher rainfall figures than the surrounding towns.

Jos which owes its origin as an important administrative and commercial centre was not founded until the twentieth century but it was preceded by two pre-colonial settlements in the vicinity atNaraguta and Guash. Early colonial officials called it Guash - following an Afizere pre-colonial settlement adjoining the foot of the hills of the present location of the Jos Museum [2].

Colonel laws who led the European occupation of the Plateau in 1903 wrote of what he saw as follows: "........ A small hill village called Guash, occupied the present location of Jos. Hausa traders who arrived supposedly mispronounced Guash for Jos and the name stuck'.

The Afizere, Anaguta and Berom all claim indigeneship of the area. Jihadist attacks and attempts to capture the area and much of the Jos Plateau in the 19th century failed. In the case of the Jos area,the combined forces of the indigenous groups successfully repelled the jihadist. However, although war failed, commercial interactions were established, as Hausa tradersmaintained tradecontacts with them at the Anaguta area of Naraguta. Following the establishment of colonial rule/administration in the 20th century, Naraguta became the first government station on the Jos Plateau being the most important town in the area. By a Government order in 1915, Jos Town was created [3] The consolidation of British colonial rule and the expansion of tin mining activities, which became the main focus of British colonization of the Jos Plateau, led to the movement of the colonial capital of the Plateau from Naraguta, to Gangare then to Tudun Wada, and finally to Rayfield. Since the imposition of colonial rule and following the development of the tin industry, commerce and administration Jos has continued to be populated by people of diverse cultural, linguistic, religious and other traditions, in a wave of endless migrations from various parts of Nigeria and beyond [4]. Jos in its compositional explanation is thus a miniature Nigeria. During colonial rule, forced and induced 
labour by the British and by virtue of imposition of labour quotas on the emirates and provinces of Northern Nigeria, and of taxation, led to the first wave of migration of many people from the Northern Provinces to Jos and tin fields. The need for clerks in the tin mines and the coming of the Railways also brought people of the southern provinces also to Jos and the tin fields. To attract labour, it was usual for managers of mining camps to arrange for importation of prostitutes, Bori dancers and the Magajiyas to brew local corn beer (Burukutu) [5]. Northernization state and local government creation as well as the search for jobs and economic opportunities in the growing Jos town also have served as pull factors. These factors made possible the growth of urban slums as well as religious and cultural diversity for which the town is known for.

Aside the introduction, this paper is structured into these parts of; the growth of urban slums; waves of migrations into the Area, Nature and dynamics of relations in Jos that is, urban slums and the circle of violence and conflicts and finally, conclusion which shall largely be the lessons from the spade of conflicts.

\section{The GRowth of URBAn Slums: WAVES OF MigRATions INTO JOS 1960-1980s}

The outbreak of the Nigerian civil war in July 1967 and the patriotic fervour whipped against the secessionists, coupled with the subsequent flexibility of the military government under General Yakubu Gowon who invited many of the political leaders to join it, although to some extent reduced regional tension but the familiar scene was one of the Igbo's moving South [6] but Northerners too were forced to flee the south east and south because they no longer felt safe. Of course as they flee away from the danger zone, their attention was turned to Jos town as their safe havens. Indeed, those of them that were of the Hausa/Fulani extraction did not have difficulties fitting themselves well into Jos town as a foundation had been laid for them where as a result of tin mining, slum settlements such as Gangare, and the Delimi Valley area extending down to Bauchi road and Ali Kazaure had been established as mining camps by the colonialists. ${ }^{1}$

It is also pertinent to note that following the creation of 12 states by the General Gowon's regime in 1967 which saw the creation of Benue Plateau State, there was also an influx of people all over the Benue and Plateau axis as well as from the North west and North east of Nigeria in search of either employment or commerce. This brought about high population pressure that necessitated the growth of slum settlements such as Gada Biyu, Tudun Wada, Angwan Rukuba, Jenta, Nasarawa Gwong and Congo Russia. Of all these slums, Tudun Wada was the most prominent because of its proximity to the state secretariat for those of them that were in the civil service, this was the most promising location to take advantage of. ${ }^{2}$

Again by 3rd February 1976, Plateau was created with

${ }^{1}$ Musa Garba Izam, Male, 78years old, Dogon-Dutse Jos, Elder Statesman/Retired Permanent Secretary, $29^{\text {th }}$ August, 2014.

${ }^{2}$ Baba Shago Itsegok Adang, Tudun-Wada Jos, Male, 88years old, Retired Civil Servant, $28^{\text {th }}$ August, 2014 thirteen Local government areas [7]. As usual; more waves of migrations took place. Another epoch in the growth of slum settlements in Jos was the inferno that engulfed the Jos Central market (Kasuwan Kantoma) in February 1974 where the market was completely burn down. At that time, the best the government thought of was that while it needed to set machinery in motion to build an ultra modern market that would span within the period of ten years, traders that lost their shops and belongings needed to be compensated and given free land to ameliorate their suffering and hardships. ${ }^{3}$ Consequently, lands at Rikkos new layout and Angwan Rogo were given out to the traders as compensation. However, most traders sold out the plots that were offered to them and in the course of time, ${ }^{4}$ these locations evolved into slums that would eventually constitute flash points as far as the history of violence and conflicts in Jos is concerned. ${ }^{5}$

By the 1980s, the waves of migrations into Jos had assumed an alarming proportion following the chains of religious violence from Kano, Jimeta,Jalingo, Kafanchanand Bauchi in December 1980, Maitatsine, a Muslim scholar wanted to purify Islam. In particular, he was against materialism and a worldly life style. Over 4,177 people died, 8,712 were wounded, and properties were destroyed [8]. These uprisings were much more severe in Kano, Jimeta Yola and Jalingo with spill over's in neighboring states. This crusade did not spare anybody from both side of the religious divide (Christianity and Islam) as people had to embark on forceful migrations to safer places and since Jos appeared to have been the most peaceful town in the north, all roads led to Jos. This also resulted in the high population build-up in the slums of Jos particularly Angwan Rogo, Rikkos Bauchi Road, Ali Kazaure and other Hausa/Fulani dominated areas as far as the Muslim are concerned. For the fleeing Christians, they had to move to the Christian dominated slums like Angwan Rukuba, Tudun Wada, Jenta, Gada Biyu and Congo Russia. ${ }^{5}$

On the 16th March 1987, what started as a minor internal misunderstanding among the Muslim and Christian students of the college of education Kafanchan, Kaduna State, finally sent sparks of fire to which the destruction went beyond Kafanchan to other parts of the state and threatened the stability of the entire country. Again because of the proximity of Kafanchan to Jos, another wave of migrations took place to add to the population pressure of the slums in Jos town. At a different spate of movement, the Bauchi crises of 1987 and the Tafawa Balewa encounters were so devastating that the impact sent a lot of inhabitants away from their domains into the Jos environment for safety.

There had also been the Wukari disturbances of 1989 , between the Jukunand Tiv in Wukari Local Government Area of defunct Gongola and now Taraba State [9]. All these instances of conflicts in other urban settings contributed in the growth of slums in Jos. The rise and subsequent growth of religious sects and movements also added to the slums in the

\footnotetext{
${ }^{3}$ Alhaji Abubakar Babanmairan, Male, 54years old, Businessman, Nasarawa Gwong Jos, $07^{\text {th }}$ September, 2014

${ }^{4}$ Alhaji Danjuma Babanmairan, Male, 68years old, Businessman, Sarki Street Jos, $07^{\text {th }}$ September, 2014

${ }^{5}$ Sir Chris Sarki Jang Jnr, Frontline Politician/Former Chairman, Jos-North LGA, Male, 64 years old, Jos Jarawa, $8^{\text {th }}$ September, 2014
} 
area of study. Key to such instances in the 80s has been the Izala movement (JIBWIS), a radical Islamic evangelical organization which lays claim to having been founded in Jos. It has very large followership throughout Nigeria. Newer religious expressions have also sought for a voice and space in Jos. These include the Grail massage, Eckanker, and Yoga among others [10]. All these have added to the population explosure in the various slums of Jos town.

\section{NATURE AND DYNAMICS OF RELATIONS IN JOS AND THE CYCLE OF ViOLENCE/CONFLICTS 1994-2010}

The conflicts in Jos can be looked at from different perspectives. By causes we mean those deep- seated factors that lead to conflict and that must be addressed and transformed to achieve sustainable peace. Conflict triggers, however, are those occurrences that capitalize on the inability to transform the deep-seated causes of conflict over time and subsequently leading to the outbreak of violence. Conflict triggers may sometimes be quite flimsy and people would wonder why simple occurrences could lead to conflict. For instance, it is difficult to understand why a young woman passing by a congregation of Muslim worshippers in her neighborhood should cause the $7^{\text {th }}$ September 2001 crisis in Jos city. Triggers become the means of venting out or convenient outlets at times when the causes of conflict are left unresolved over time.

In Jos, the causes of conflict can be reduced to the following, albeit not exhaustive list of factors: land/ territorial ownership, indigeneity contestation, politics and power and religion and ethnicity.

\section{A. Land Ownership}

In the African sense, land ownership is tied to history, ancestral and traditional rights, religion, traditional, power and authority, citizenship, belongingness and a host of other psychological needs. When people make forceful argument about owning a place, they derive such ownership from land and history. Thus, in Jos there is a conflict of who owns Jos, and this is between the Hausa-Fulani elements on the one hand and the Afizere, Anaguta and Berom on the other.

\section{B. Citizenship}

As indicated above, citizenship derives its argument and principles from land and landownership. Resolving who owns the land goes directly to answer who is a citizen, and in this case expressed in the sharp divide between indigenes and settlers. Indigene ship in this context is used to refer to those who first settled on the land and, therefore, own the land. The difference between indigenes and non-indigenes is that the indigenes are assumed within the local community to have certain traditional, political and economic rights that the non-indigenes do not. These rights are not supported by Law or the 1999 constitution of the Federal Republic of Nigeria, but they are expectations that derive from the practice of Nigerian federalism. Thus, the Afizere, Anaguta and Berom reason that the Hausa-Fulani are not indigenes of Jos simply because they own the land. This is, indeed, a Nigerian problem that manifests throughout the country.

\section{Politics and Power}

In Jos as in other parts of the state, power is shared and controlled on the basis of land-ownership, ownership of towns and settlements, and citizenship or, remotely put, where people come from. It is expressed in two ways. The first is at the traditional realm, where the institution of traditional ruler ship is involved. In tradition, chieftaincy institutions are exclusive prerogative of indigenes, and in many cases royal indigenes. It becomes provocative for nonindigenes, and in many cases royal indigenes to aspire or even attempt to aspire to such positions.

Further to this is the politics around the machinery of modern government exhibited via appointments and recruitments into the public service, the uniformed services, scholarship awards, representative and elective offices through partisan politics, appointive positions, etc. The quota available to each local government and to Jos North is contested, and because these are political resources, citizenship along the lines of indigenes and non-indigenes becomes a significant criterion for access. Those who believe that they are indigenes wish to have firmer control of the political resources of the land, sometimes to the detriment and exclusion of the assumed settlers. Thus, it is the competition for political resources that has functionalized land and citizenship identity into causes of conflict.

\section{Religion, Ethnicity, Indigineship}

It is sometimes suggested that the conflict in Jos is religious. While it is true that all of these conflicts have religious and ethnic colorations, these factors add up to the question of identity and are not strictly casual. It is in a bid by parties to the conflict to find satisfiers to their needs in conflict that they inevitably organize themselves into one identity group or the other. Thus, those who want to exclude others from the political and traditional resources of an area will identify themselves as "indigenes" and refer to the others as "settlers". Similarly, it becomes convenient for people to divide themselves into "Christian" and "Muslim" identities in order to pursue certain agenda and interests as well as exclude and discriminate against the others. These divisions also fall to serve the lines of mobilization, the vehicle to perpetrate violence and to identify targets of attacks. Although these conflicts may provoke issues closely related to these aforementioned forms of identity, the identities only perform their traditional functions of demarcation/segregation, mobilization and ideology in the context of the conflicts of Jos. The conflicts are hardly ever about religion, ethnicity or citizenship. This is to the extent that no religious group has ever been denied the right to practice freely nor ethnic group asked to leave, and no persons have been sent out on account of whether they are indigenes or settlers. Instead, there is evidence that the political and economic elite in the area sometimes collaborate to share and benefit from the common resources and opportunities meant for the people by creating conflicts and disharmony among the people.

For a better understanding of the nature and dynamics of relations in Jos and the circle of violence and conflicts a brief explanation of the episodes is hereby offered.

\section{E. April 1994 Episode}

The first major conflict in the town since independence 
occurred on April 12th, 1994 during which some local markets and roundabouts were either destroyed or defaced. The 1994 conflict was the culmination of three years of tension occasioned by the creation of Jos North Local Government by the military regime of Babangida in 1991. The circumstances leading to the creation of the new LGA was as controversial as the immediate post creation days, all indicating that political contests in the LGA promised to be keen and interesting. The forces instrumental to and credited with the creation of the LGA were the Jasawa (Hausa/Fulani) They wrote and presented a memorandum to that effect, in their quest for self-determination and as part of the claim to owning Jos. Once created the LGA was divided into fourteen electoral wards namely; Gwong, Vander Puye, Tafawa Balewa, Abba Na Shehu, Naraguta A, Naraguta B, Gangare, Garba Daho, Ali Kazaure, Ibrahim Katsina, Kabong, Tudun Wada, Jenta and Sarkin Arab. The population estimate of the young LGA by 1991 census was 450,000 as it covered a landmass of $1695 \mathrm{sq} \mathrm{km}$.

The Berom, Afizere and Anaguta opposed the new LGA on two counts. Firstly, they were not consulted in the exercise and more so the Local Government boundaries were arbitrarily fixed to their disadvantage. Secondly, the creation of wards favored the Hausa/Jasawa dominated areas as those areas had more wards but which were small in population while the indigenes had fewer but larger populated wards. The impact of the lopsided creation of wards, indigenes argue, has to do with election by ward delegates, which place them at a disadvantage. ${ }^{6}$ Thus, while Jasawa Development Association rejoiced at the announcement of the creation of the LGA, the indigenes brooded and openly demonstrated against it. Babangida did not listen to the anti-creation complaints and the LGA remained. The Afizere and Anaguta later called a press conference in which they accepted the reality but the Berom remained opposed, as they were worst affected by the boundary problem created by the creation of the LGA. They also called a press conference in which they condemned the government, the JDA and the consenting indigenous groups. No change occurred, as tension gripped the town.

In furtherance of his transition program Babangida formed the two political parties, National Republican Convention (NRC) and Social Democratic Party (SDP) and democratized LGs and for the first time elections into Local Councils were held on party basis. The ethno-religious character of politics in Jos manifested. Ab initio the two parties went with religious and ethnic identities in the minds of many voters. In this context the NRC was regarded as northern, conservative, Hausa/Fulani and Muslim, while the SDP was regarded as southern/middle belt, progressive and Christian. In fact, religion played a key role in the determination of the winner and loser even in the gubernatorial election in the then Plateau State. At the Jos North Local Government level the religio-ethnic/regional classification of the parties was also made manifest as the Jasawa supported the NRC, while the indigenes supported the SDP. The chairmanship candidates

${ }^{6}$ Pius Gimba, Ukadum-Jos, Community Leader/Politician, Male, 57years old, $8^{\text {th }}$ September, 2014 for the local polls similarly reflected this stereotyping and division. The SDP candidate was a Berom Christian whilst the NRC Candidate was a Hausa Muslim. The NRC won the election amidst complaints of ballot fraud from indigenes, contributing to the tension in the town. The immediate cause of the 1994 conflict was associated with the appointment of Sanusi Mato, a Hausa (Jasawa) to the position of Jos North LGA Management Committee Chairman by Col. Muhammed Mana, then Military administrator of Plateau State [11]. The protest of the indigenes against the creation of the Local Government and efforts to reverse the creation of the Local Government fell on deaf ears. The riots of 1994 became a vent for the pent-up tension over this politics and the frustrations it generated on both sides of the conflict divide.

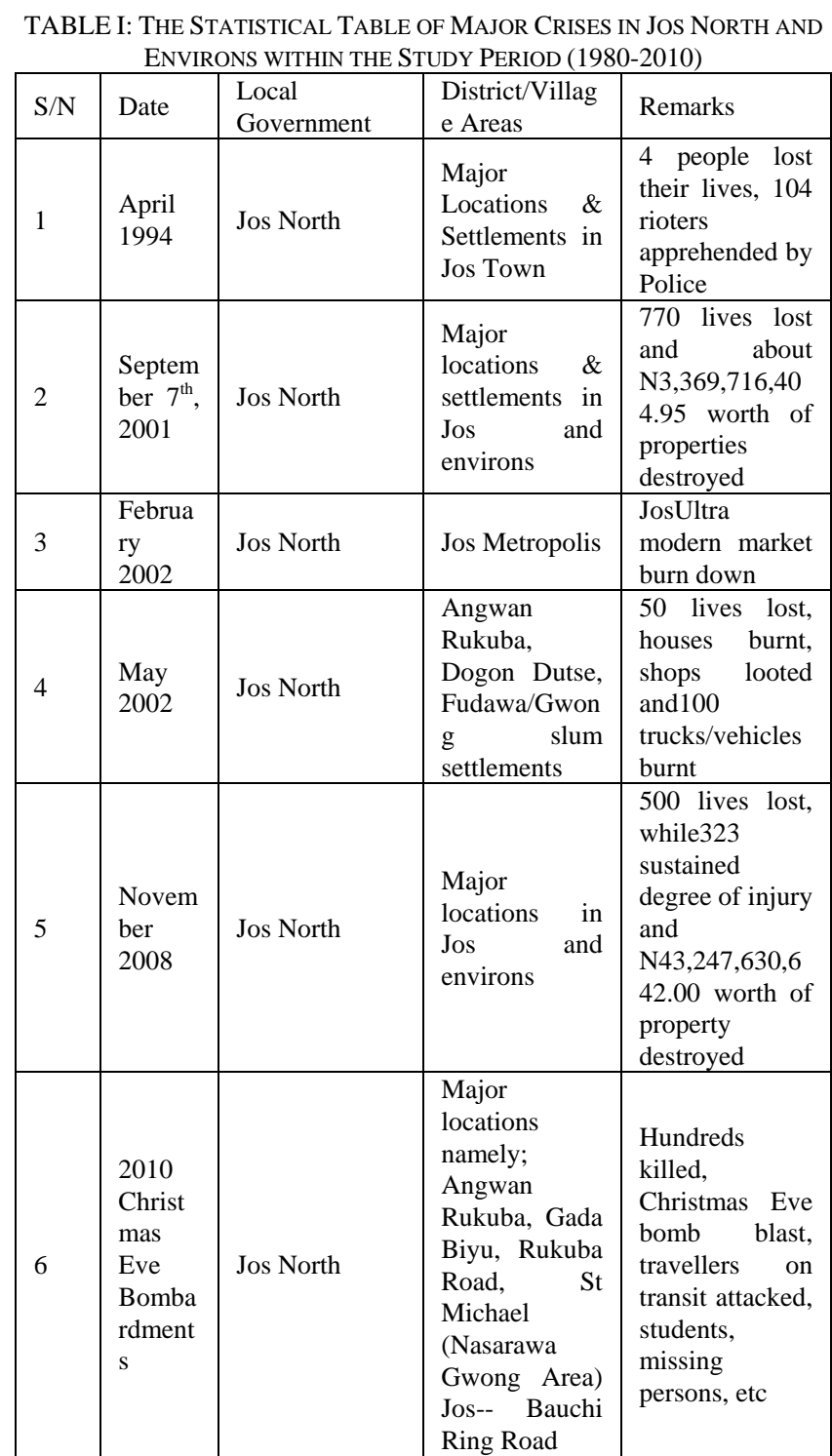

Source: 1. J. J. David kaleidoscope of conflicts in plateau state: Balancing peace with development, pp.14-17. 2. Field work conducted from $28^{\text {th }}$ August to 7 September, 2014.

\section{F. September 2001 and May 2002 Crises}

The September 7-12, 2001 was the most serious armed conflict in Jos when Jos, the capital city, experienced unprecedented carnage that changed the face of the once serene city. The once peaceful virgin was ravished by violent conflict [12]. In this conflict, politics has been implicated as are other factors such as religion, and ethnicity. For example, 
while there were underlying factors such as the indigene-settler problem, the immediate trigger was the appointment of Mallam Muktar, also a Hausa (Jasawa), as Plateau State coordinator of the Federal Government Poverty Alleviation Agency called National Poverty Alleviation Program (NAPEP). This came with different dimension of interpretations along ethnic and religious lines, leading to insidious writings of threats along the same lines. It will however be misleading to agree to the position peddled about a young lady passing by when prayers were in progress. This can at best be referred to as a trigger. This is confirmed by the events of February and May 2002. The first mishap to befall the state in 2002 was the orchestrated burning of the Jos ultra-modern market in February. By May 22, 2002, Naraguta ' $\mathrm{B}$ ' ward, a slum within the vicinity of Angwan Rukuba was boiling as a result of Local Government Peoples Democratic Party (PDP) Ward congress convened to select party delegates for the local government council. The Hausa or Jasawa elements had mobilized themselves from all over their slum settlements and converged at Gwong, headquarters of Naraguta ' $\mathrm{B}$ ' ward on a mission to frustrate the emergence of late Frank Bagudu Taddy as delegate at the congress which would have terminated his bid to re-contest for the chairmanship of the LGA. ${ }^{7}$ At the venue, violence erupted and eventually spread all over Jos and environs leading to destruction of lives and properties.

\section{G. November 2008 Crisis}

Although like the preceding conflicts, the complicating factors in the 2008 crisis were "ethnicity, religion, local history, local politics, the ambivalent state of Nigerian law on the subject of indigene rights and, perhaps most harmfully and most intractably, corrupt and incompetent government" [13]. The political issue was at the forefront asthe immediate trigger in the 2008 crisis which came in the aftermath of a cancellation of the local government poll in November of the same year. On a rescheduled election on November 27th, 2008 elections were held into political offices at the local government level across Plateau State. The day of the election was generally quite calm as elections were held across the local government areas without any civil disturbances particularly in Jos North Local Government Area. In the early hours of November $28^{\text {th }}, 2008$ as the election results were being brought to the collation centre at RCM primary school Kabong, it was said that some youths had started mounting road blocks at the Bauchi Road area of Jos, alleging that the election into the chairmanship seat of Jos North Local Government had been rigged. Their agitations were founded base on the fact that Government had for first time in history decided to, relocated the Local government election collation centre which used to be the Jos North Local Government Secretariat to the said RCM primary school in Kabong just on the eve of the election. There was commotion all through the night as a result of the rumours of rigging at the new collation centre. Shortly after it was reported that there was violence, it took no time to spread into these slum settlements. The situation remained tense on

${ }^{7}$ Haruna Gini Umaru, Bauchi Road, Jos, Elder/Politician, Male, 67years old, $28^{\text {th }}$ August, 2014
November 29th, 2008 even though the violence had reduced because of the presence of security agents. However, the Plateau State government held the view that the violence had nothing to do with the local government elections but was part of the underhand devise by political opponents to discredit the government and make the state ungovernable as basis to call for the declaration of a state of emergency. Thus, far, in Jos town, the fear of politics: elections and appointments is the beginning of security wisdom.

\section{H. 2010 Christmas Eve Bombings}

It all began like a rumour that "Christians will not celebrate the 2010 Christmas in peace that year", but with passage of time things started unveiling. At about 7:00pm there were simultaneous bomb blasts at Angwan Rukuba and Sauki Hotel. Report say the number of the wounded taken to the hospital was thirty, and dead bodies at the scene were twenty three. The second blast happened at a beer parlour and all in the beer parlour were killed and about twenty five wounded. Meanwhile, at about the same time i.e. five minutes past 7:00pm on the same night of $24^{\text {th }}$ December, four bomb blasts exploded at various locations of the slums of Kabong - Gada Biyu Jos. Sixteen people were killed while many people were injured and properties were destroyed.

Some youths in the Nasarawa Gwong area, enraged by the attacks and killings, suspected to be targeted at Christians or non-Hausa residential areas, sought to revenge the killings. Some four persons were said to have been killed. Sporadic shooting and burning of Christian and Muslim Houses and places of businesses became the order of the day. Nevertheless, security intervention stopped the violence. The December $24^{\text {th }}$ attacks was certainly a terrorist attack carefully planned and designed to destroy the holy period that means so much to Christians.

\section{CONCLUSION}

The research has been able to establish that the growth of slums in Jos and environs has been highly influenced by series of activities ranging from growth and expansion in both government and religious institutions particularly the growth of Almajiri camps, commerce, and migrations. The immigration of people into Jos became much pronounced during and after the civil war and heightened to its peak in the 80 s following the spade of intra and inter religious and ethnic uprising within the north. It has also established that the failure of authorities to consider critically the underlying social and political factors and to bring the perpetrators of these crises to book is responsible for these repeated attacks. A new terrorist strategy has been born in Nigeria and we are now stuck with fanatical religious groups with links to the terrorist Al-Qaeda organization. From the ordinary use of knives and arrows we have moved up a step higher to use bombs (IEDs) to blast people out of existence. This is a step away from suicide bombing. As part of the most plausible suggestions to the problem of the growing slums is for government to embark on a title audit and verification, it should also embark on a weapons search alongside the dismantling of criminal hubs in these slums through the building of schools, recreational facilities, hospitals, roads 
and worship centres. The bridging the gap project in segregated communities is important, so also is the building of rapid response security barracks in these slums to curb the excesses of these youths. We also submit that there is the need for new cities to be designed and provided with services, this will be allocated to individuals to build on it.

It should be noted that each time there is a crisis and we call it a religious crisis, it causes more damage to lives and properties. Religion is a very sensitive issue. This explains why in the last census religion was excluded from the questionnaire. When we appeal to religious sentiments, many of our people easily become victims of manipulation. They easily lose the power of reasoning and can do anything in the name of protecting or defending their religion. The more we focus on our crisis as a religious one, the more we shall prolong the problem. Once a crisis is said to be religious, we arouse the sentiment of outsiders who feel they must identify with their co-religionists to fight for their faith. Little wonder that even those in leadership positions, business, academia, security, and the media begin to see the issues not from an objective point of view but through the lens of religion and efforts are made to support their co-religionists, thus attracting attention to the crisis and prolonging violence. There must be a multidimensional approach as enumerated above to this complex problem on the Jos Plateau.

\section{REFERENCES}

[1] A. D. Bingel, "Jos: Origin and Growth of the Town 1900-1972," Department of Geography University of Jos Publication No.1, Nigeria, pp. 1-2, 1978.

[2] S. U. Fwatshak and V. S. Dugga, "Conflicts and cooperation in the politics of jos north LGA of plateau state, central Nigeria, 1991-2008" Nasarawa Journal of General Studies, vol. 1, no. 1, pp. 55-61, 2011.

[3] S. U. Fwatshak, "Comparative analysis of the $19^{\text {th }}$ and $21^{\text {st }}$ century religious conflicts on the jos plateau, central Nigeria," SMT, vol. 94, no. 3, 2006.

[4] M. Y. Mangvwat, "A history of class formation in the plateau province 1902-1960: The genesis of a ruling class," Ph.D. Thesis, Dept. History, ABU Zaria, 1984.

[5] A. D. Nyam, Colonialism and Intergroup Relations in the Central Nigeria Highlands: The Afizere Story, Aboki Publishers, Abuja, p. 205, 2011.

[6] M. H. Kukah, Religion, Politics and Power in Northern Nigeria, Spectrum Books Limited, Abuja, pp. 185-202, 2003.

[7] J. J. David, "Kaleidoscope of conflict in plateau state: Balancing peace with development (ND), a publication of directorate of research and planning, governor's office PMB 2069, government house ray field," Jos, Plateau State, Nigeria, pp. 3-26, 2013.

[8] S. A. Abdullahi, "Ethnicity and ethnic relations in Nigeria: The case of religious conflict in Kano in July Carter," in Regional and Ethnic Conflicts: Perspectives from the Front Line, G. Irani and V. Volkan, Eds., Pearson Education, Upper Saddle River, New Jersey, 2008.

[9] M. Hamman, "Inter - ethnic relations and inter - ethnic conflicts," in Northern Nigeria: A Century of Transformation, A. M. Yakubu, I. M. Jumare, and A. G. Saeed, Eds., Arewa House, Centre for Historical
Documentation and Research, Ahmadu Bello University, P.O. Box 171 Kaduna, Nigeria, 1903-2003.

[10] S. G. Best, Causes and Effects of Conflicts in the Southern Zone of Plateau State, Nigeria, Ibadan-Nigeria, John Archeres Publishers Ltd University of Jos, pp. 10-20, 2008.

[11] S. D. Mwadkwon, "Religion, the settler question and ethnic conflicts in Jos," SMT, vol. 89, no. 1, pp. 67-69, 2002.

[12] I. A. Kaigama, Peace not War: A Decade of Interventions in the Plateau State Crises, Hamtul Press Ltd, Bisichi Jos, pp. 12-89, 2012.

[13] P. Ostein. Jonah Jang and the Jasawa: Ethno - religious conflicts in Jos, Nigeria. Muslim - Christian Relations in Africa. [Online]. Available: http://www.sharia-in-africa.net/pages/publications.php

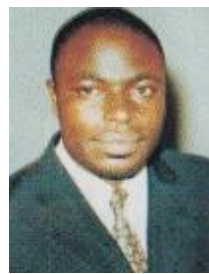

David Nyam Ajiji was born in Fobur of Jos East Local Government Area of Plateau State, Nigeria, on March 2, 1965. He attended the famous Ahmadu Bello UniversityZaria, where he obtained a diploma in civil law in August 1991. He obtained a BA (hons) degree in history and international studies from the University of Jos, in 2006 and a master of arts (MA) degree in history from the same University in 2009 with specialty on boundaries and intergroup relations.

He worked as a senior clerical officer with the High Court of Justice, Jos in 1996 and rose to the rank of registrar and area court judge respectively before withdrawing his service in 2012. He picked up an appointment with Federal University Lafia, Nasarawa state, Nigeria, in July 2012 as a lecturer II in the Department of History. He is currently doing a lot of work on boundaries, intergroup relations, conflicts and displacements in the central nigeria area and biographical writing.

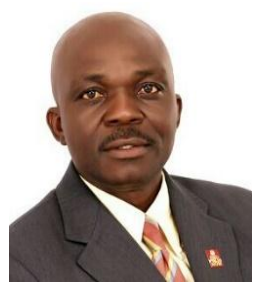

Larab Tangshak Ayuba was born on September 15, 1976 in Jos now Jos North Local Government Area of Plateau State Nigeria. He holds a bachelor's degree in history, a postgraduate diploma in Museology, a master degree in law and diplomacy and economic history. Larab has series of trainings in conflict and peace studies Alongside peacebuilding as fields of endeavour. $\mathrm{He}$ is currently a Ph.D candidate in diplomatic studies. He specialises in cross-cultural studies with a strong bias for negotiation and mediation.

In terms of work engagement, he has worked for the past decade as a researcher and teacher rising to the rank of lecturer I in the Department of History and International Studies of the University of Jos. He has to his credit over twenty-five published chapters in books and articles in high impact peer review journals. Larab is a member of the Historical Society of Nigeria, (MHSN), a member of the Association of African Historians, (AAH), a member of the Pan-African History Society (MPAHS), a member of the International Council on Museums (ICOM), a member of the International Committee on Museology (ICOFOM), a fellow of Institute of Public Diplomacy and Management (FIPDM) and a chartered member of the Institute of Chartered Mediators and Conciliators (ICMC). Larab is married to Juyira. 